\title{
THE RELATIONSHIP BETWEEN QUALITY OF STUDENT CONTRIBUTION IN LEARNING ACTIVITIES AND THEIR OVERALL PERFORMANCES IN AN ONLINE COURSE
}

\author{
Rajabalee Yousra Banoor [y.rajabalee@uom.ac.mu],University of Mauritius, Mauritius, \\ Frank Rennie [Frank.Rennie@ubi.ac.uk], University of Highlands and Islands, United Kingdom, \\ Mohammad Issack.Santally [m.santally@uom.ac.mu],University of Mauritius, Mauritius
}

\begin{abstract}
In this research we studied the correlation between the level of students' online participation and their overall performances. We examined in this study, the participation level in different learning activities assigned to two large cohorts of learners, and compared them with their final grades at the end of the year. We defined the quality of their participation in the online course as being classified into the level of learning activities in which they participated. Learning activities were grouped into four levels which were identified namely at the knowledge, understanding, critical thinking skills and practical competencies. The findings revealed that participation in higher-order online learning activities, that is the higher ability to show critical skills and practical competencies, resulted in better grades of the learners in the module. However, the results also highlighted that overall students had a tendency to score more marks in the knowledge category as the activities required lower order cognitive skills. It was further observed that low performers demonstrated a tendency to obtain lower marks in all the four grouping levels and vice-versa for high performers. Two key elements can be concluded from the findings. The first aspect is about instructional design of such online courses where there is a need for the inclusion of learning activities targeted at the development of different types of skills, and second is the distribution and weighting given to these categories. The recommendation is that for first year students, a greater weighting of marks toward knowledge level activities will generally encourage good performances, and this could be gradually reviewed when they move on to level 2 onwards in their studies.
\end{abstract}

\section{Abstract in French}

Dans cette étude, nous avons étudié la corrélation entre le niveau de participation en ligne des étudiants et l'ensemble de leurs performances. Nous avons examiné le niveau de participation dans les différentes activités d'apprentissage attribuées à deux groupes d'apprenants et les avons comparées à leurs notes finales à la fin de l'année. Nous avons défini la qualité de leur participation dans le cours en ligne en fonction des activités d'apprentissage auxquelles ils ont participé. Les activités d'apprentissage ont été regroupées en quatre niveaux, à savoir les connaissances, la compréhension, les capacités de réflexion critique et les compétences pratiques. Les résultats ont révélé que la participation dans des activités d'apprentissage en ligne nécessitant des compétences d'ordre cognitive supérieur, a permis d'obtenir de meilleurs résultats dans le module. Cependant, les résultats ont également montré que les étudiants avaient tendance à avoir plus de points dans la catégorie des connaissances, car les activités nécessitaient des compétences cognitives de niveau inférieur. Il a également été observé que les étudiants moins performants manifestaient une tendance à obtenir des notes plus faibles dans les quatre niveaux de regroupement et vice-versa pour les plus performants. Deux éléments clés peuvent être conclus à partir des résultats. Le premier aspect concerne la conception pédagogique de ces cours en ligne où il est nécessaire d'inclure des activités d'apprentissage ciblées sur le développement de différents types de 
compétences, et la seconde est la distribution et la pondération accordée à ces catégories. La recommandation est que pour les étudiants de première année, une plus grande pondération des notes vers les activités de niveau de connaissances encouragera généralement de bonnes performances, et cela pourrait être revu graduellement quand ils passeront au niveau 2 dans leurs études.

\section{Introduction}

The integration of technology in teaching and learning has been transforming the traditional mode of instruction. The widespread use of technological devices has become a significant means of delivery of course contents, thus creating opportunities to make learning accessible from everywhere and at any time. Learners have the possibility of interacting, collaborating, contributing and participating in their online courses, irrespective of the time and location. Santally and Senteni (2013) could not conclude that a relationship exists between adapting content to be delivered to students based on their learning styles and their overall performances in a module. They postulate that achievement of the learner may also be based on aspects such as engagement to the course and learning consolidation through revision. Cheng and Chau (2016) highlight the relevance and significance of online participation and interaction in an online course, for effective learning to occur. Moreover, the emergence of digital technologies and the widespread access of open educational resources as a flexible approach to education brought a wide range of facilities for the learners to integrate both formal and informal learning (McGloughlin \& Lee, 2010). Learners can maintain their learning space and participate, interact and socially engage in discussion fora, blogs and eLearning platforms (Cunningham, 2015; Dabbagh \& Kitsantas, 2012; Ke, 2010). Hence, this can empower the learners for autonomous and self-regulated learning. Although learners' interaction, participation and completion of activities have been indicators of their engagement, it can also be significant to analyse the quality of learner participation, which is a key driver to determine and predict learning outcomes and performances. Considerable research has found that the quality, as well as the quantity, of participation needs to be addressed for learning performance (Abrami et al., 2011; Bernard et al., 2009; Chan \& Chan, 2011; Naranjo et al., 2012).

\section{Factors affecting student performances in online course}

The advancement and potential of digital technology and its integration in teaching and learning have given rise to a growing number of online courses which resulted in an increased number of enrolled learners (Moore \& Kearsley, 2005; Simonson et al., 2009). Learners, whether they are oncampus or online, are the essential asset of an institution and their academic performance and achievement can determine the future of the country's economic and social development (Norhidayah et al., 2009) as it helps to find out if they are skilfully employable in the job market. Harvey's (2000) study stated that graduates' employability has been found to be a pressing issue on the Government's mandate in many countries, given that the public frequently contributes to higher education investment (HEFCE-PISG, 1999), which in turn contribute to the national economic growth (Harvey, 2000).

Learners' communication skill is one of the key factors that can affect their academic performance directly, as it is an essential and primary element to be used in the collaborative online environment. Online learning is not simply passive, but it is achieved through networking, communication and knowledge exchanges between tutor-learner and learner-to-learner (Cohen \& Prusak, 2001; Lave \& Wenger, 1991; Nonaka \& Konno, 1998). Communication is strongly associated with learners' performances because it stimulates learners to actively participate, collaborate and engage in social exchanges, via course discussion fora and bulletin boards using online collaboration tools. Generally, since online learning is structured and based predominantly on assessment-based 
activities and participation, where communication serves as the basis for social interaction, contribution and collaboration, the latter becomes an influential factor in learner performance. A study carried out by Beaudoin (2002), assumed that improved learners' interaction levels increase the effectiveness of both classroom and online courses. Consequently, communication can have a direct impact on the learning performance of learners, but most importantly, it affects those who are reluctant to getting engaged in discussions in the learning community. Mushtaq (2012) also supported the fact that communication affects learners' performance in e-Learning environments and identified that there is a positive correlation between them.

Tutors frequently play a significant role in online courses and they act as online facilitators to the learners. A study by Vonderwell and Zachariah (2005) on the factors that affect learners' participation online, found that learners' participation was influenced by the technology and design interface. Interestingly, in a similar study, Vrasidas and McIsaac (1999) found that computer mediated communication is the central element that affects learners' interaction. Various research studies (Arbaugh, 2002; Arbaugh \& Duray, 2002; Hong, 2002; Piccoli et al., 2001) have also demonstrated the importance of learner attitudes towards technology as being an important factor in e-learning. Therefore, tutor guidance is a critical element that can influence and shape learners' study attitudes and habits, which in turn will impact on their academic performance. Tutors can instruct the learners on how to foster positive attitudes and adjust to learning with technology, as proper guidance will help them to perform better (Hussain, 2006). Proper academic guidance is determined as a contributing factor in learners' performances, achievement and satisfaction (Ferrer de Valero, 2001; Earl-Novell, 2006; Lovitts \& Nelson, 2000).

\section{Quality of student participation in online courses}

McCoubrie (2004) and Case and Swanson (2001; pp.22-25) postulated on the use of Multiple Choice Questions (MCQs) as being a determinant to assess knowledge. Similarly, during the study of de Wever et al. (2009), researchers (McLoughlin \& Luca, 2002; Dennen \& Paulus, 2006; Robinson \& Udall, 2006; Larres et al., 2003) argued the value of self-assessment and discussion activities as being a means to assess learners' academic standards (Gibbs, 2006), effective social contributions (Sluijsmans et al., 1999; Freeman \& McKenzie, 2002; Robinson \& Udall, 2006) and knowledge construction (Dennen \& Paulus, 2006). Consequently, the result of these specific activities indicated the quality of participation in which knowledge building processes occur (Cacciamani et al., 2012). Richardson (2010) supported the fact that blogging activities encouraged learners' critical and analytical skills and are a means to enhance and promote their creative thinking abilities for academic writing. Similarly, it was also mentioned (Lin et al., 2006) that blogging activities can contribute to learner engagement by improving their communication and critical thinking skills. Researchers identified concept mapping as a graphical tool that can be used in the assessment of learners' understanding of what they have learned (Sugihara et al., 2012; Yoshida et al., 2013; Nomura et al., 2014; Alkhateeb et al., 2015; Hirashima et al., 2011; 2015). Hence, a method to assess learners' understanding is meaningful to judge their quality (level) of participation. Activities that require the learners to carry out practical assignments, demonstrating their thinking and understanding through prototypes, have been found to be reliable in assessing practical skills and the application of knowledge (Toplis \& Allen, 2012; Dimkov et al., 2011; Millar, 2010). Thus, the assessment of learners' abilities to model their ideas is a suitable criteria for evaluating the quality of participation and performance in a course. Hence, as supported by Greller et al. (2017), learner participation and commitment is a contributing element to academic success and the completion of a course. 


\section{The research context and hypothesis}

The aim of the research study is to understand how variables such as the nature and quality (level) of student participation in online activities impacts on their overall performance. In this context, the research question that has been addressed is as follows:

\section{"What is the relationship between quality of student participation (knowledge, understanding, critical thinking, practical skills) in learning activities and their performances in the online course?"}

\section{Methodology}

The total population of this research study consisted of two cohorts of learners, enrolled on an online course, which was assessed through activity-based learning. The online course was a generic course, with open enrolment across all faculties of the University. Therefore, learners from different faculties had the possibility of enrolling on this online course, which was offered over one academic year consisting of 2 semesters of 15 weeks. The number of students for each cohort was 235 and 870 respectively, and they were all first-year university students. Data about the learners related to their performances in terms of overall grades and marks in the different learning activities of the online course.

The main approach was to use descriptive learning analytics. In an academic context, learning analytics occur as a result of course data combined with learning sciences, which is interpreted in an educational context. The concept of learning analytics describes the process of filtering these data, systematically quantifying them, and interpreting their meaning, so they can contribute to the improvement of teaching and learning (Macfadyen \& Dawson, 2012). Recent studies (AgudoPeregrina et al., 2014; Macfadyen \& Dawson, 2010; Tempelaar et al., 2013; Wolff et al., 2013) have shown that recording learners' behaviour can help to discover patterns that can lead to prediction, and with learning analytics these patterns of data can be indicators of outcomes which, if addressed, can substantially help to improve academic performance.

While learners' consistent engagement is an important element for a successful learning experience, their quality of participation throughout different learning activities is also a reliable predictor to measure learning outcomes. In this study, a rubric was used to assess the quality of learners' participation based on a series of learning activities assigned to the learners. There were nine learning activities in all, consisting of participation in a discussion forum, online Multiple Choice Questions (MCQs), self-reflection, blogging and practical activities. The rubric consisted of four indicators namely knowledge, understanding, critical thinking skills, and practical competencies. The use of rubrics to quantify and measure the quality of participation is efficient as it can be used as a measurable scale with guidelines for fair assessment. The first aspect was to normalise the marks as for the knowledge category: the maximum allowable marks were 40, for critical and practical skills the upper limit was set to 20 , while for understanding they could have a maximum of 10 marks. Based on the rubrics that were devised as evaluative criterion in this study, the various learning activities which yielded the following skills are described below. 
Table 1: Rubric Indicators for assessing quality of participation

\begin{tabular}{|c|c|c|c|c|}
\hline Indicators & & Description & $\begin{array}{l}\text { Weightage } \\
\text { (marks) }\end{array}$ & $\begin{array}{l}\text { Marks per } \\
\text { Indicator }\end{array}$ \\
\hline \multirow[t]{5}{*}{ Knowledge Acquisition - 25\% } & Activity 1 & Discussion Forum & 10 & 40 marks \\
\hline & Activity 2 & Online Quiz - Multimedia \& Learning & 10 & \\
\hline & Activity 3 & Online Forum activity & 10 & \\
\hline & Activity 4 & Online Quiz - Audio \& Video & 10 & \\
\hline & & Technologies & & \\
\hline \multirow[t]{2}{*}{ Critical Thinking Skills - 25\% } & Activity 5 & Blog Critical Reflection Activity & 10 & 20 marks \\
\hline & Activity 7 & YouTube Video Comment Activity & 10 & \\
\hline $\begin{array}{l}\text { Understanding (Knowledge } \\
\text { Deepening) }-25 \%\end{array}$ & Activity 6 & Concept Mapping activity & 10 & 10 marks \\
\hline \multirow[t]{3}{*}{ Practical Competencies - $25 \%$} & Activity 8 & Educational Website Development & 10 & 20 marks \\
\hline & Activity 9 & Application of eLearning Authoring Tool & 10 & \\
\hline & & Overall Maximum Mark & 90 & \\
\hline
\end{tabular}

\section{Knowledge acquisition}

Learning activities 1, 2, 3 and 4 were activities that promoted learning and assessed how much the learner had assimilated and then evaluated his or her knowledge from the responses. Activity 1 was a discussion forum activity, where learners were encouraged to communicate and collaborate by exchanging ideas on a specific topic. Activity 2 and 4 were quizzes activities, which consisted of a variety of types of questions, including multiple choice, single answer and true/false questions. Activity 3 was self-reflection activity, where the learner tried to communicate to the tutor and their peers about their prior knowledge on some background concepts. The outcome of these activities provided a method for assessing learner's knowledge, derived from their choice of answers and their ability to explain their choice and defend their opinions.

\section{Critical thinking skills}

Learning activities 5 and 7 were activities that helped to determine the relative importance for assessing learner's critical skills and level of comprehension. Activity 5 was a blog activity, where the learner needed to go through two articles and demonstrate their understanding of the main points being discussed. Then forging a personal opinion, the learner was required to post constructive comments as well as reply to peers' comments. In parallel, Activity 7 was a YouTube activity, where the learner was exposed to the concept of online video lectures and required to reflect on the potential of such approaches in educational settings after viewing two videos from the channel. The outcome of these activities provided a method to determine the extent to which instruction given to students helped them to think critically, assess their reasoning abilities, and acquire mastery of the content knowledge by formulating their own opinions.

\section{Understanding (knowledge deepening)}

Learning activity 6 was an activity which provided a method for assessing learners' understanding through a teaching technique that explained the connection between ideas, helping students to organize and structure their thoughts to understand specific information. This activity was based on the use of concept mapping to visually organise information in a schematically way to demonstrate the understanding of concepts and to communicate ideas.

\section{Practical competencies}

Learning activities 8 and 9, were activities which determined the learner's proficiency in creating and developing a product by applying into practice the theory which had been learned. It provided a method for assessing learners' practical competencies and performance that implied the use of 
specific techniques acquired during the course. These practical activities required the learner to design and develop learning resources through the use of educational technology tools. The learners had the option to choose two authoring tools out of three proposed; these were NVU, eXe Learning, and Cartoon Story Maker. While the NVU authoring tool is used to design and develop web pages, using a WYSIWYG editor, the eXe Learning is an application which practically allows learners to create self-contained web pages which can be published for different environments. Similarly, the Cartoon Story Maker, is an educational tool which allow learners to create a pedagogical scenario-based story, which can then be exported as HTML web-pages. These two assignments were outcome based with respect to the course learning outcomes, as learners had to demonstrate their skills acquired throughout the course.

\section{Findings}

A correlation of overall performance was carried out with the level/types of activities which learners participated in (a) grouped by faculties and (b) grouped by gender. We started by looking at the overall results to get a broader view of the overall students' performances, and then narrowed the focus to the specific correlation of each level of activities to the overall performances. Overall there was no significant difference between the performances of male and female learners as shown by the figures below. When looked at in the context of the faculty, it can be deduced that female students performed significantly better than male students only at the Faculty of Science $(p<.05)$ at $95 \%$ confidence interval. With respect to the overall performances of learners in relation to the different faculties that they come from, it was found that the overall performances from the Faculty of Agriculture, Science, Engineering, Law and Management were significantly higher than the Faculty of Social Sciences and the Humanities.

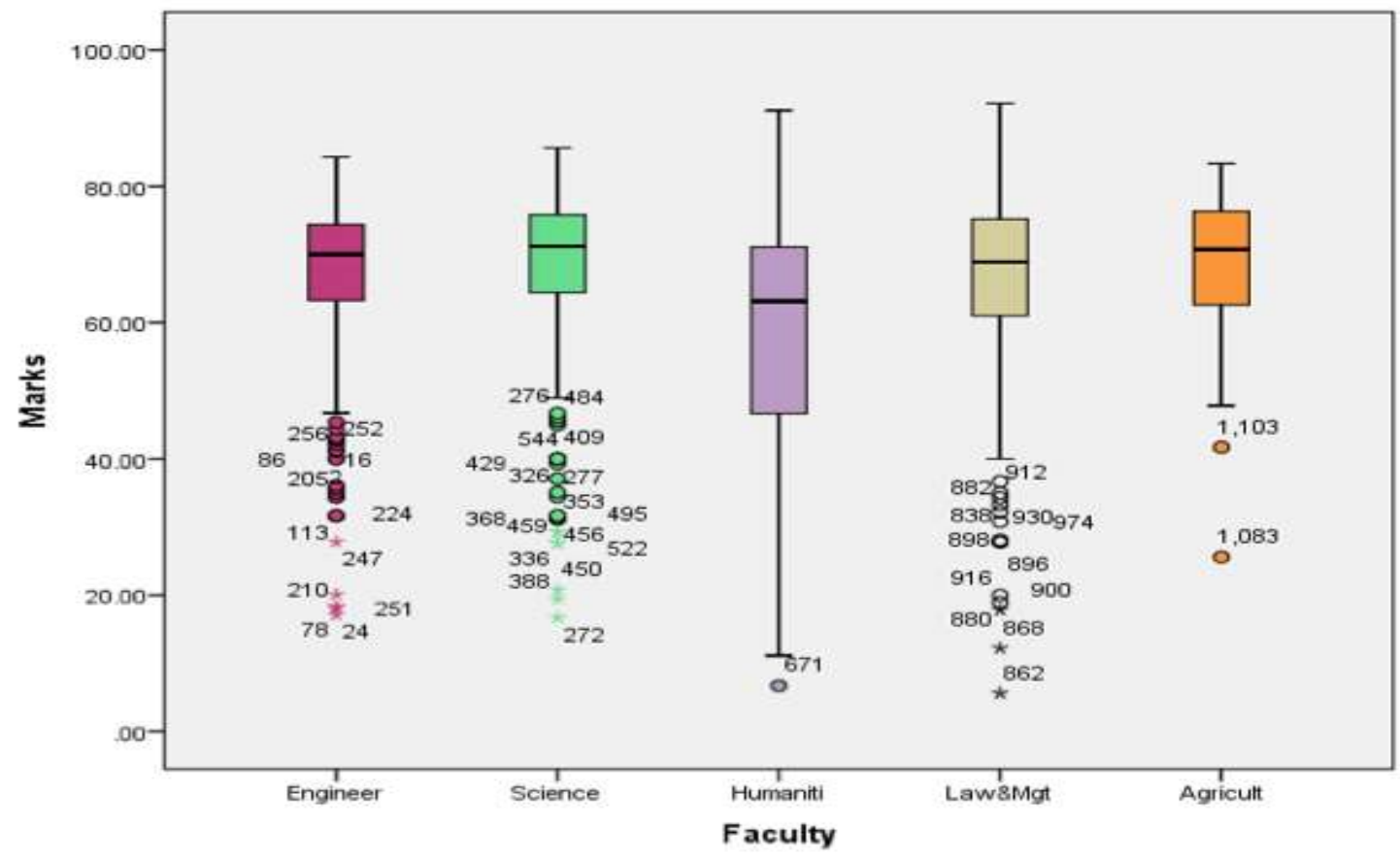

Figure 1.

In terms of the level of activities, the box plot as shown reveals that students scored significantly higher in terms of activities falling in the knowledge category that is at the lowest cognitive level. These activities focused more on recall of knowledge and consisted of basic forum postings and multiple choice questions. Interestingly fairly consistent marks were noted in the other activities falling under the understanding, critical thinking skills, and practical competencies categories. 


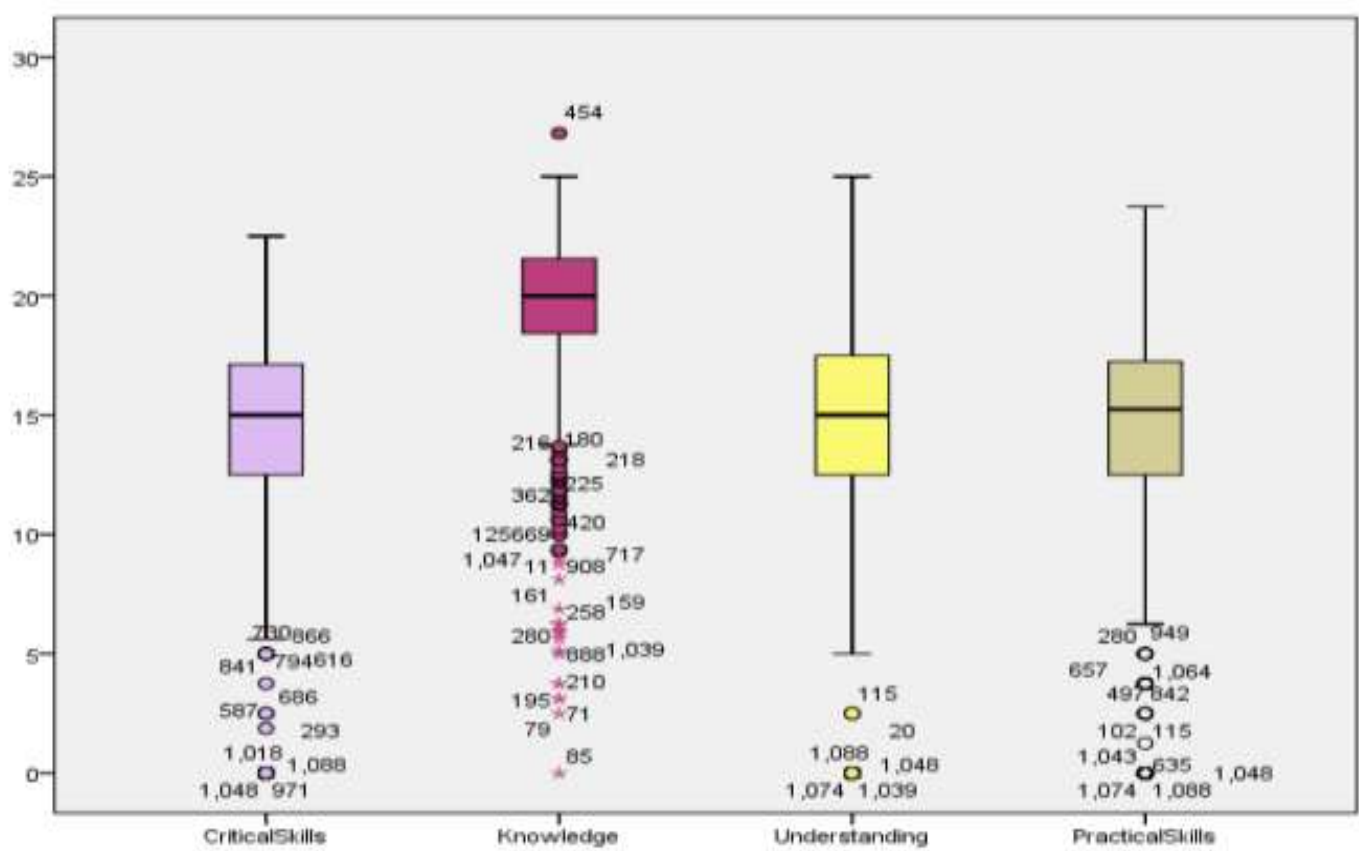

Figure 2.
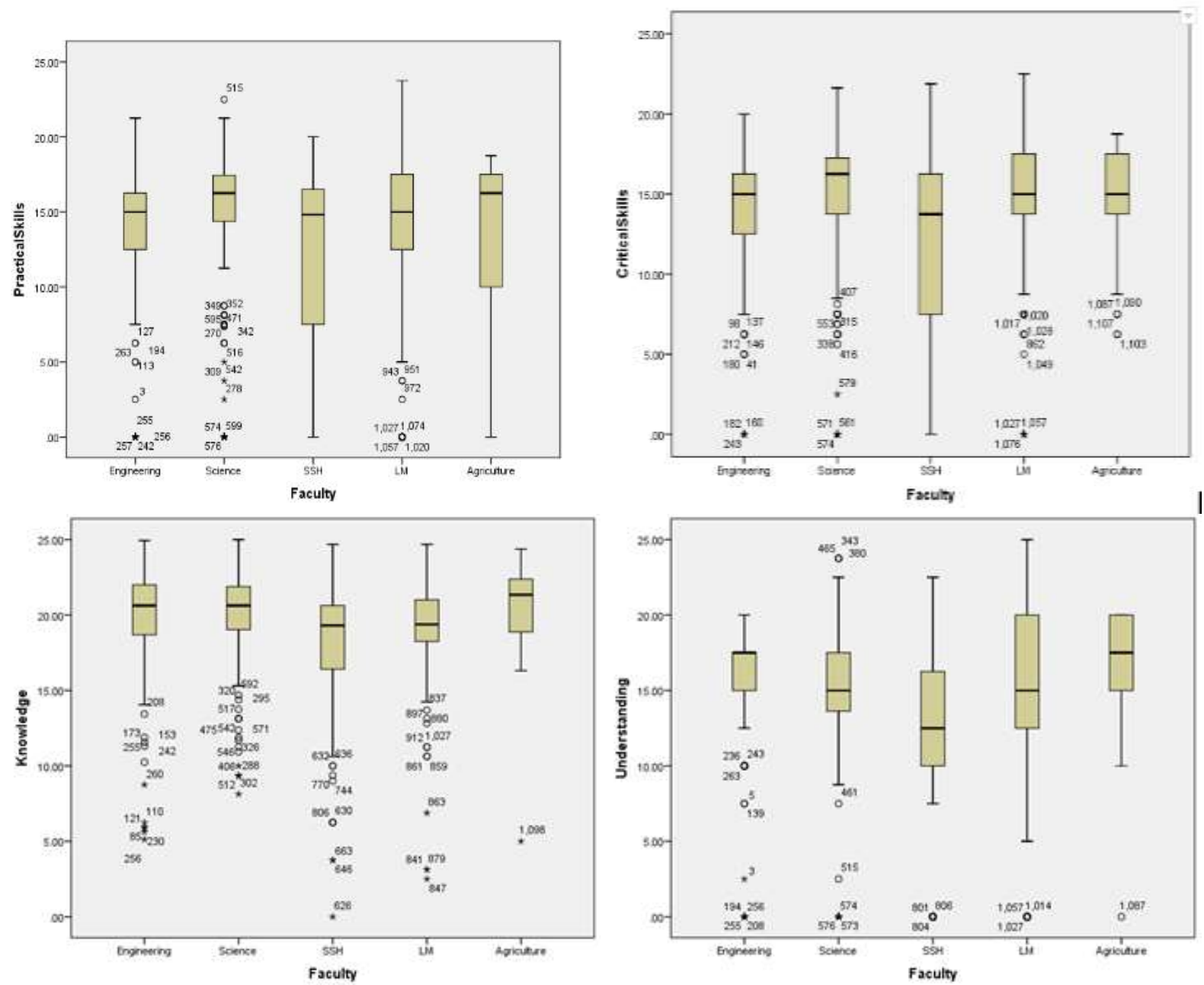

Figure 3. 
Looking now at the data in the faculty context for each of the categories, it was observed that the trends are similar to the overall performances per faculty. In each of the categories, it was noticed that the scores for the Faculty of Social Studies and the Humanities were significantly lower than for the other faculties. In terms of critical thinking skills and practical competencies, the distribution is found to be rather broad for the Faculty of Social Studies and Humanities (SSH) as compared to a relatively compact distribution for the other faculties. The t-test confirms that overall, the marks scored in the four categories by the students are significantly lower for SSH as compared to the other faculties. The box plots also reveal that that for the knowledge category, the upper mark limits were quite close to the maximum allowable mark for each of the faculties. This is mainly explained by the fact that students from the SSH faculty were among those who could be classified as the least proficient in terms of Information and Communication Technologies (ICTs) within the student population that followed the module. While it is clear that students' marks within each category are positively correlated to the overall performance, we calculated the Pearson's correlation coefficient for each category with normalised marks. A strong positive correlation was found for each of the categories $(\varrho=0.8)$ with a moderately positive one for the knowledge category $(\varrho=0.6)$. For each of the categories, we further classified students' achievements into three sub-levels (High for $\mathrm{x}>=70$; Moderate for $50<=\mathrm{x}<70$ and Low for $\mathrm{x}<50$ ). The table below illustrates the correlation coefficient for each of the categories.

Table 2:

\begin{tabular}{|c|c|c|}
\hline Category & $\begin{array}{l}\text { Correlation } \\
\text { Coefficient }\end{array}$ & Remarks \\
\hline Knowledge & $\begin{array}{l}\text { High }-0.386 \\
\text { Moderate }-0.190 \\
\text { Low }-0.233\end{array}$ & Weak positive correlation to overall performance for all levels. \\
\hline Understanding & $\begin{array}{l}\text { High }-0.306 \\
\text { Moderate }-0.492 \\
\text { Low }-0.740\end{array}$ & $\begin{array}{l}\text { Weak positive relationship for High and Moderate achievers in the three } \\
\text { categories, with a moderately strong relationship for the Low achievers in the } \\
\text { Critical Thinking Skills, Understanding and Practical Competencies category. }\end{array}$ \\
\hline Critical Thinking & $\begin{array}{l}\text { High }-0.341 \\
\text { Moderate }-0.459 \\
\text { Low }-0.675\end{array}$ & \\
\hline Practical Skills & $\begin{array}{l}\text { High }-0.270 \\
\text { Moderate }-0.344 \\
\text { Low }-0.706\end{array}$ & \\
\hline
\end{tabular}

From the above table, a moderately strong positive correlation is present for those who earned relatively low marks in the Practical Competencies, Critical Thinking Skills and Understanding categories while a weak positive correlation was present for understanding for all the three levels (High, Low, Moderate). This suggests that if those who had low marks in the three categories (Understanding, Critical thinking skills and Practical Competencies) had made efforts to improve their marks in the related learning activities, the impact on improving their overall performances would have been more significant than if those who scored low marks in the Knowledge category made additional effort to improve their marks in that specific category. To confirm our initial observations, contingency tables were prepared to look at the number of students who performed low, moderate and high for each category (Knowledge, Critical thinking, Understanding and Practical competencies) and the number for each level who performed correspondingly in the overall performances. This was done both for the normalised marks (all the components treated on equal weighting) and for the original marks (with knowledge category having a higher weighted score compared to the other categories). 
Table 3-4:

\begin{tabular}{|c|c|c|c|c|c|c|}
\hline & & & \multicolumn{3}{|c|}{ OveralliPerformancesLevel } & \multirow[b]{2}{*}{ Total } \\
\hline & & & Average & High & Low & \\
\hline \multirow[t]{6}{*}{ CategoryLevel } & CriticalSkillsAverage & Count & 412 & 160 & 32 & 604 \\
\hline & & Expected Count & 314.8 & 192.1 & 97.1 & 604.0 \\
\hline & CriticalSkillsHigh & Count & 66 & 192 & 3 & 261 \\
\hline & & Expected Count & 136.0 & 83.0 & 42,0 & 2610 \\
\hline & CriticalSkillsLow & Count & 99 & 0 & 143 & 242 \\
\hline & & Expected Count & 126.1 & 77.0 & 38.9 & 2420 \\
\hline \multirow[t]{2}{*}{ Total } & & Count & 577 & 352 & 178 & 1107 \\
\hline & & Expected Count & 577.0 & 352.0 & 178.0 & 1107.0 \\
\hline
\end{tabular}

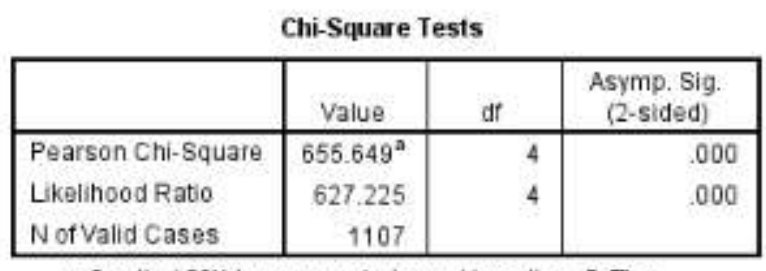

a. 0 cells $(.0 \%)$ have expected count less than 5 . The minimum expected count is 38.91 .

Chi-square test of independence were performed with regards to the number of performers at each level and the corresponding overall performances. For the normalised data, it was found that the variables were dependent. For example, since Low performers correlate well with Low performers for overall for the different cases, it is natural to have a strong relationship between the two categories and thus a very small p-value. It is therefore clear that high performers had generally performed well in all the categories when the data were normalised and vice-versa for low performers.

Given that the total sum of marks originally allocated to the Knowledge category represented around $40 \%$ of the overall course, contingency tables were also devised using un-normalised data to look at the extent that the chi-square tests of independence might differ. From the table below it can be seen that about $80 \%$ of the total students of the two cohorts, and who performed highly in Knowledge Categories were in fact high overall performers, as compared to about only $35 \%$ of the total students who would have been high performers if they performed well in Knowledge categories when data was normalised (i.e. all categories distributed with equal weighting). 
Table 5-6:

Categorylevel ' OverallPerformancestevel Crosstabulation

\begin{tabular}{|c|c|c|c|c|c|c|}
\hline & & & \multicolumn{3}{|c|}{ OverallPerformancesLevel } & \multirow[b]{2}{*}{ Total } \\
\hline & & & Average & High & Low & \\
\hline \multirow[t]{9}{*}{ CategoryLevel } & KnowledgeAverage & Count & 25 & 109 & 23 & 157 \\
\hline & & Expected Count & 17,3 & 131.9 & 78 & 1570 \\
\hline & & Resiđual & 7.7 & .22 .9 & 15.2 & \\
\hline & KnowledgeHigh & Count & 94 & 800 & 12 & 906 \\
\hline & & Expected Count & 99.8 & 761.1 & 45.0 & 906.0 \\
\hline & & Residual & -5.8 & 38.9 & -33.0 & \\
\hline & KnowledgeLow & Count & 3 & 21 & 20 & 44 \\
\hline & & Expected Count & 4.8 & 37.0 & 2.2 & 440 \\
\hline & & Residual & -1.8 & -16.0 & 17.8 & \\
\hline \multirow[t]{2}{*}{ Total } & & Count & 122 & 930 & 55 & 1107 \\
\hline & & Expected Count & 122.0 & 930.0 & 55.0 & 1107.0 \\
\hline
\end{tabular}

\begin{tabular}{|l|r|r|r|}
\hline & \multicolumn{1}{|c|}{ Chi-Square Tests } \\
\hline & Value & df & $\begin{array}{c}\text { Asymp. 8ig. } \\
\text { (2-sided) }\end{array}$ \\
\hline Pearson Chi-Square & $216.318^{2}$ & 4 & 000 \\
Likelihood Ratio & 125.088 & 4 & 000 \\
N of Valid Cases & 1107 & & \\
\hline
\end{tabular}

a. 2 cells $(22.2 \%)$ have expected count less than 5 . The minimum expected count is 2.19 :

From a statistical perspective, the test of independence was still inconclusive, and the variables still showed a high degree of correlation. However, significant changes were noticed in the contingency tables for each category when the un-normalised data were used. This shows clearly how the actual overall performances of the students were affected and influenced for the majority of them by the raw marks they scored in the activities falling under the knowledge category.

\section{Discussion}

The module on education technologies was offered to mainly first year students of the University of Mauritius as a general education module. Students from all the five faculties enrolled on the module. The module required students to demonstrate practical skills in the use of ICT-related tools such as web authoring as well as the need to demonstrate understanding and critical thinking skills through concept mapping and online argumentation (blogging and reflective journals). While the module was strongly centred on Information and Communication Technologies (ICTs), students did not a priori need to possess advanced technical skills to do well in the module. However, digital literacy skills are considered a desirable set of skills to assist in the smooth adaptation of the students in the module. Accordingly, those students in the Humanities generally did less well overall than those in the Sciences or Engineering. The end of course feedback from the students confirmed the tendency that the digital skills of the students, their familiarity with online modules, and the use of ICT tools could have contributed to these results.

Irrespective of the assigned faculty it was also noticed that students had clearly focused on the knowledge related activities to collect maximum marks, perhaps because these were deemed to be the easiest ones as they consisted of the completion of online quizzes and knowledge acquisition activities (such as writing down definitions on forum spaces). The students could score up to 40 marks in these activities, which would contribute to their overall marks. It is therefore suggestive that the learning activities related to knowledge acquisition would contribute more significantly to the final performance grades of the students. A very strong relationship was established between 
those who had high marks in these activities and their overall performances. It was also found that strong positive relationships existed where those who had worked very well in the module, had in general worked well in all the components of that module. This confirms the findings of Beaudoin (2002) and Greller et al. (2017) that students who show higher degrees of commitment, i.e. learner engagement, will normally be more likely to have better performance grades.

Given that the final performances will be heavily influenced by the knowledge acquisition categories, the marks were normalised to see how things would present if all the categories carried equal weight. Interestingly, we found that for those who had low overall performances, knowledge acquisition would have a lower impact on the overall results than the activities needing higher order cognitive inputs and the practical activities. This is a significant finding from an instructional design perspective. While the allocation of a maximum of 40 marks in the knowledge acquisition category for first year students contributed to higher pass rates and overall good performances, it may be deduced that a different balance of the weighting could have helped low achievers to improve their overall performances. Students may have either consciously or subconsciously developed a complacent attitude towards the end of the module, after having achieved the minimum pass requirements for the module. If the weightings of other components were increased, students might conceivably have engaged more in critical skills activities, which could lead to a better performance in the knowledge creation and skills-building in the practical learning activities.

While the findings bring some clarity to the course mechanics and how things resulted in this module, it also illustrates how the performance of students could have been different if parameters had been adjusted differently. These considerations could then inform pedagogical conception and instructional design decisions. The first element is the need for careful instructional design of online courses, particularly where there is an intention to include learning activities targeted at the development of different types of skills. Second one is the need for careful consideration in the distribution of marks and the weighting given to these categories of activities. A recommendation is that for first year students a greater weighting of marks toward knowledge level activities will generally contribute towards high performances, and this could be gradually reviewed to include more critical evaluation skills as students move on to level 2 onwards in their studies. This is a form of learning analytics, mainly referred to as descriptive analytics. In line with Macfadyen and Dawson (2012), we can see this technique has helped to give some constructive meaning to the data gathered on the e-Learning platforms so as to better understand our students' learning patterns. In turn, this can be used to revise pedagogical design to improve on the teaching and learning of online modules. The findings in this research lead us to reflect further on the potential of learning analytics in different forms, namely descriptive analytics which can present both the teacher and the learner with data about student interaction with online learning resources and their resulting contribution patterns of communication during the module. Real-time data gathering about students' interactions can help predict a trend or tendency towards certain performance levels, and consequently could help students to achieve improved learning outcomes.

\section{Conclusion}

In this research educational data was collected for a large number of students who were enrolled on an online module at the University of Mauritius, in an attempt to understand the relationship between the quality of student participation in online learning activities and their overall performances in the online course. It was concluded that the students had a general tendency to attempt more knowledge level activities and to score more marks in these activities. Those who performed very well in the module, performed generally well in all the different categories. Those who performed on the low side in general scored low marks in the other categories of learning activities. The weighting given to all learning activities also plays an important role and the 
knowledge acquisition category scores had more influence on the overall performances than other individual learning activities. However, it appears to be more important that the instructional design of courses is done in such a way that critical thinking skills development are promoted by a more balanced distribution of marks, as was found that when the weightings were normalized. Low achievers may have scored better if they put in some more effort to score higher marks in critical thinking related activities.

\section{References}

1. Abrami, P. C., Bernard, R. M., Bures, E. M., Borokhovski, E., \& Tamim, R. M. (2011). Interaction in distance education and online learning: Using evidence and theory to improve practice. Journal of Computing in Higher Education, 23(2-3), 82-103.

2. Agudo-Peregrina, Á. F., Iglesias-Pradas, S., Conde-González, M. Á., \& Hernández-García, Á. (2014). Can we predict success from log data in VLEs? Classification of interactions for learning analytics and their relation with performance in VLE-supported F2F and online learning. Computers in Human Behavior, 31, 542-550.

3. Alkhateeb, M., Hayashi, Y., \& Hirashima, T. (2015). Comparison between Kit-Build and Scratch-Build Concept Mapping Methods in Supporting EFL Reading Comprehension. The Journal of Information and Systems in Education, 14(1), 13-27.

4. Arbaugh, J. B. (2002). Managing the online classroom: a study of technological and behavioral characteristics of web-based MBA courses. Journal of High Technology Management Research, 13, 203-223.

5. Arbaugh, J. B., \& Duray, R. (2002). Technological and structural characteristics, student learning and satisfaction with web-based courses - An exploratory study of two on-line MBA programs. Management Learning, 33(3), 331-347.

6. Beaudoin, M. F. (2002). Learning or lurking? Tracking the "invisible" online student. The internet and higher education, 5(2), 147-155.

7. Bernard, R. M., Abrami, P. C., Borokhovski, E., Wade, C. A., Tamim, R. M., Surkes, M. A., \& Bethel, E. C. (2009). A meta-analysis of three types of interaction treatments in distance education. Review of Educational research, 79(3), 1243-1289.

8. Cacciamani, S., Cesareni, D., Martini, F., Ferrini, T., \& Fujita, N. (2012). Influence of participation, facilitator styles, and metacognitive reflection on knowledge building in online university courses. Computers \& Education, 58(3), 874-884.

9. Case, S. M., \& Swanson, D. B. (2001). Constructing written test questions for the basic and clinical sciences $\left(2^{\text {nd }}\right.$ ed.). Philadelphia: National Board of Medical Examiners

10. Chan, C. K., \& Chan, Y. Y. (2011). Students' views of collaboration and online participation in Knowledge Forum. Computers \& Education, 57(1), 1445-1457.

11. Cheng, G., \& Chau, J. (2016). Exploring the relationships between learning styles, online participation, learning achievement and course satisfaction: An empirical study of a blended learning course. British Journal of Educational Technology, 47(2), 257-278.

12. Cohen, D., \& Prusak, L. (2001). In good company: how social capital makes organizations work. MA, Boston: Harvard Business Press.

13. Cunningham, J. M. (2015). Mechanizing People and Pedagogy: Establishing Social Presence in the Online Classroom. Online Learning, 19(3), 34-47. 
14. Dabbagh, N., \& Kitsantas, A. (2012). Personal Learning Environments, social media, and self-regulated learning: A natural formula for connecting formal and informal learning. The Internet and higher education, 15(1), 3-8.

15. Dennen, V. P., \& Paulus, T. M. (2006). Researching "collaborative knowledge building" in formal distance learning environments. In T. Koschman, T. W. Chan \& D. D. Suthers (Eds.), Computer supported collaborative learning 2005: The next 10 Years! International Society of the Learning Sciences, Taipei.

16. Dimkov, T., Pieters, W., \& Hartel, P. (2011). Training students to steal: a practical assignment in computer security education. Proceedings of the $42^{\text {nd }} A C M$ technical symposium on computer science education, 21-26.

17. Earl-Novell, S. (2006). Determining the extent to which program structure features and integration mechanisms facilitate or impede doctoral student persistence in mathematics. International Journal of Doctoral Studies, 1, 52-55.

18. Ferrer de Valero, Y. (2001). Departmental factors affecting time-to-degree and completion rates of doctoral students at one land-grant research institution. The Journal of Higher Education, 72(3), 341-367.

19. Freeman, M., \& McKenzie, J. (2002). SPARK, A Confidential Web-Based Template for Self and Peer Assessment of Student Teamwork: Benefits of Evaluating across Different Subjects. British Journal of Educational Technology, 33, 551-569.

20. Gibbs, G. (2006). How assessment frames student learning. In C. Bryan \& K. Clegg (Eds.), Innovative assessment in higher education (pp. 23-36). London: Routledge.

21. Greller, W., Santally, M. I., Boojhawon, R., Rajabalee, Y., \& Kevin, R. (2017). Using Learning Analytics to Investigate Student Performance in Blended Learning Courses. Journal of Higher Education Development - ZFHE, 12(1).

22. Harvey, L. (2000). New realities: the relationship between higher education and employment. Tertiary Education and Management, 6, 3-17.

23. HEFCE-PISG (1999). Performance indicators in higher education. First report of the performance indicators steering group, 99/11. Bristol: HEFCE.

24. Hirashima, T., Yamasaki, K., Fukuda, H., \& Funaoi, H. (2011). Kit-Build Concept Map for Automatic Diagnosis. Proceedings of Artificial Intelligence in Education 2011, Auckland, New Zealand: Springer-Verlag Berlin Heidelberg, 466-468.

25. Hirashima, T., Yamasaki, K., Fukuda, H., \& Funaoi, H. (2015). Framework of kit-build concept map for automatic diagnosis and its preliminary use. Research and Practice in Technology Enhanced Learning, 10(1), 1-21.

26. Hong, K. S. (2002). Relationships between students' and instructional variables with satisfaction and learning from a Web-based course. Internet and Higher Education, 5, 267-281.

27. Hussain, Ch. A. (2006). Effect of Guidance Services on Study Attitudes, Study Habits and Academic Achievement of Secondary School Students. Bulletin of Education and Research, 28(1), $35-45$.

28. Ke, F. (2010). Examining online teaching, cognitive, and social presence for adult students. Computers \& Education, 55(2), 808-820.

29. Larres, P. M., Ballantine, J. A., \& Whittington, M. (2003) Evaluating the validity of selfassessment: Measuring computer literacy among entry-level undergraduates within accounting degree programmes at two UK universities. Accounting Education, 12, 97-112. 
30. Lave, J., \& Wenger, E. (1991). Situated learning: legitimate peripheral participation. Cambridge, UK: Cambridge University Press.

31. Lin, W.-J., Yueh, H.-P., Liu, Y.-L., Murakami, M., Kakusho, K., \& Minoh, M. (2006). Blog as a tool to develop e-learning experience in an international distance course. Proceedings of the Sixth IEEE International Conference on Advanced Learning Technologies (ICALT'06).

32. Lovitts, B., \& Nelson, C. (2000). The hidden crisis in graduate education: Attrition from Ph.D. programs [Electronic version]. Academe Online.

33. Macfadyen, L. P., \& Dawson, S. (2010). Mining LMS data to develop an "early warning system" for educators: A proof of concept. Computers \& Education, 54(2), 588-599. http://dx.doi.org/10.1016/j.compedu.2009.09.008

34. Macfadyen, L. P., \& Dawson, S. (2012). Numbers are not enough. Why e-learning analytics failed to inform an institutional strategic plan. Educational Technology \& Society, 15(3), 149-163.

35. McCoubrie, P. (2004). Improving the fairness of multiple-choice questions: a literature review. Medical teacher, 26(8), 709-712.

36. McGloughlin, C., \& Lee, M. J. W. (2010). Personalised and self regulated learning in the Web 2.0 era: International exemplars of innovative pedagogy using social software. Australasian Journal of Educational Technology, 26(1), 28-43

37. McLoughlin, C., \& Luca, J. (2002). A learner-centred approach to developing team skills through web-based learning and assessment. British Journal of Educational Technology, 33(5), 571 582.

38. Millar, R. (2010). Analysing practical science activities to assess and improve their effectiveness. Hatfield: Association for Science Education.

39. Moore, M. G., \& Kearsley, G. (2005). Distance education: A systems view (2 ${ }^{\text {nd }}$ ed.). Belmont, CA: Wadsworth Publishing Company.

40. Mushtaq, S. N. K. (2012). Factors affecting students' academic performance. Global Journal of Management and Business Research, 12(9).

41. Naranjo, M., Onrubia, J., \& Segués, M. T. (2012). Participation and cognitive quality profiles in an online discussion forum. British Journal of Educational Technology, 43(2), 282-294.

42. Nomura, T., Hayashi, Y., Suzuki, T., \& Hirashima, T. (2014). Knowledge Propagation in Practical Use of Kit-Build Concept Map System in Classroom Group Work for Knowledge Sharing. Proceeding of International Conference on Computers in Education Workshop 2014, Nara, Japan: ICCE 2014 Organizing Committee, 463-472.

43. Nonaka, I., \& Konno, N. (1998). The concept of BA: Building a foundation for knowledge creation. California Management Review, 40(3), 40-54.

44. Norhidayah, A., Kamaruzaman, K., Syukriah, A., Najah, M., \& Azni Syafena Andin, S. (2009). The Factors Influencing Students. Performance at Universiti Teknologi MARA Kedah, Malaysia. Canadian Research \& Development Center of Sciences and Cultures: Vol.3 No.4.

45. Piccoli, G., Ahmad, R., \& Ives, B. (2001). Web-based virtual learning environments: a research framework and a preliminary assessment of effectiveness in basic IT skill training. MIS Quarterly, 25(4), 401-426.

46. Richardson, W. (2010). Blogs, wikis, podcasts, and other powerful web tools for classrooms. Corwin Press. 
47. Robinson, A., \& Udall, M. (2006). Using formative assessment to improve student learning through critical reflection. In C. Bryan \& K. Clegg (Eds.), Innovative assessment in higher education (pp. 92-99). New York: Routledge.

48. Santally, M., \& Senteni, A. (2013). Effectiveness of Personalised Learning Paths on Students Learning Experiences in an e-Learning Environment. European Journal of Open, Distance and eLearning, 2013(I). Retrieved from http://www.eurodl.org/materials/contrib/2013/Santally_Senteni.pdf

49. Simonson, M., Smaldino, S., Albright, M., \& Zvacek, S. (2009). Teaching and Learning at a Distance: Foundations of distance education ( $4^{\text {th }}$ ed.). Columbus, OH: Prentice-Hall.

50. Sluijsmans, D., Dochy, F., \& Moerkerke, G. (1999). Creating a Learning Environment by Using Self-, Peer- and Co-Assessment. Learning Environments Research, 1, 293-319.

51. Sugihara, K., Osada, T., Nakata, S., Funaoi, H., \& Hirashima, T. (2012). Experimental evaluation of kit-build concept map for science classes in an elementary school. Proceedings of Computers in Education 2012, Singapore: National Institute of Education, 17-24

52. Tempelaar, D. T., Heck, A., Cuypers, H., van der Kooij, H., \& van de Vrie, E. (2013). Formative Assessment and Learning Analytics. In D. Suthers \& K. Verbert (Eds.), Proceedings of the $3^{\text {rd }}$ International Conference on Learning Analytics and Knowledge (pp. 205-209). New York: ACM. http://dx.doi.org/10.1145/2460296.2460337

53. Toplis, R., \& Allen, M. (2012). I do and I understand? Practical work and laboratory use in United Kingdom schools. Eurasia Journal of Mathematics, Science \& Technology Education, 8(1), 39 .

54. Vonderwell, S., \& Zachariah, S. (2005). Factors that influence participation in online learning, Journal of Research on Technology in Education, 38(2), 213-230.

55. Vrasidas, C., \& McIsaac, M. (1999). Factors influencing interaction in an online course. The American Journal of Distance Education, 13(3), 22-36.

56. de Wever, B., van Keer, H., Schellens, T., \& Valcke, M. (2009). Structuring asynchronous discussion groups: the impact of role assignment and self-assessment on students' levels of knowledge construction through social negotiation. Journal of Computer Assisted Learning, 25(2), 177-188.

57. Wolff, A., Zdrahal, Z., Nikolov, A., \& Pantucek, M. (2013). Improving retention: Predicting at-risk students by analysing clicking behaviour in a virtual learning environment. Paper presented at the $3^{\text {rd }}$ International Conference on Learning analytics and Knowledge.

58. Yoshida, K., Sugihara, K., Nino, Y., Shida, M., \& Hirashima, T. (2013). Practical Use of KitBuild Concept Map System for Formative Assessment of Learners' Comprehension in a Lecture. Proceedings of Computers in Education 2013, Bali, Indonesia: Asia-Pacific Society for Computers in Education, 906-915. 